\title{
Inhibition of Calcitriol Receptor Binding to Vitamin D Response Elements by Uremic Toxins
}

Sanjeevkumar R. Patel, Hui-Qiong Ke, Raymond Vanholder, ${ }^{\ddagger}$ Ronald J. Koenig, * and Chen H. Hsu

Nephrology Division and *Endocrinology and Metabolism Division, Department of Internal Medicine, University of Michigan Medical School, Ann Arbor, Michigan 48109-0364; and ${ }^{\ddagger}$ Nephrology Division, Department of Medicine, University Hospital, Ghent University, Ghent, Belgium

\begin{abstract}
The genomic action of calcitriol (1,25-dihydroxy-vitamin $\left.\mathrm{D}_{3}\right)$ is mediated through the interaction of the calcitriol receptor (VDR) with vitamin D response elements (VDREs). Although renal failure is associated with resistance to the action of calcitriol, the mechanism of this resistance is not well understood. Therefore, we used the electrophoretic mobility shift assay to compare the ability of VDRs from normal and renal failure rats to bind to the osteocalcin gene VDRE. The results indicate that VDRs from renal failure rats have only half the DNA binding capacity as VDRs from control rats, despite identical calcitriol binding. Furthermore, incubation of normal VDRs with a uremic plasma ultrafiltrate resulted in a loss of $>50 \%$ of the binding sites for the osteocalcin VDRE. When VDRs bound to DNA as heterodimers with retinoid $X$ receptors, the inhibitory effect of the uremic ultrafiltrate was due to a specific interaction with the VDR, not retinoid $X$ receptors. In addition, uremic ultrafiltrate blocked calcitriol-induced reporter gene activity in transfected JEG-3 cells. Taken together, the results indicate that an inhibitory effect of a uremic toxin(s) on VDR-VDRE binding could underlie the calcitriol resistance of renal failure. (J. Clin. Invest. 1995.96:50-59.) Key words: electrophoretic mobility shift assay - vitamin $D$ response element • uremia $\cdot$ renal failure $\cdot$ calcitriol resistance
\end{abstract}

\section{Introduction}

The calcitriol (1,25-dihydroxy-vitamin $\left.\mathrm{D}_{3}\right)$ receptor $(\mathrm{VDR})^{1}$ is a nuclear protein of the erbA superfamily that regulates gene expression in a ligand-dependent manner (1). The hormonereceptor complex interacts with specific DNA sequences (vitamin D response elements, VDREs), generally located in the $5^{\prime}$

Address correspondence to Chen H. Hsu, MD, 3914 Taubman Center, Nephrology Division, University Hospital, Ann Arbor, MI 48109-0364. Phone: 313-936-9480; FAX: 313-936-9621.

Received for publication 28 February 1994 and accepted in revised form 29 March 1995.

1. Abbreviations used in this paper: CAT, chloramphenicol acetyltransferase; EMSA, electrophoretic mobility shift assay; GH, growth hormone; $N_{\max }$, maximal binding capacity; N-UF, normal ultrafiltrate; $\mathrm{RXR} \alpha$, retinoid X receptor $\alpha$; U-UF, uremic ultrafiltrate; VDR, calcitriol receptor; VDRE, vitamin D response element.

J. Clin. Invest.

(C) The American Society for Clinical Investigation, Inc.

0021-9738/95/07/0050/10 \$2.00

Volume 96, July 1995, 50-59 flanking regions of target genes, and thus regulates the transcription of those genes. The resulting changes in protein expression are ultimately responsible for the biological activity of calcitriol $(2,3)$. Renal failure is associated with resistance to the action of calcitriol. For example, absorption of intestinal calcium remained lower in uremic rats compared with normal rats receiving pharmacological doses of calcitriol (4); parathyroid hormone is elevated despite a normal plasma concentration of calcitriol in renal failure (5); and chronic replacement of calcitriol failed to normalize calcitriol metabolic clearance (6) and intestinal 24-hydroxylase activity in renal failure (7). However, the underlying mechanisms are not well understood. We have shown previously that uremic ultrafiltrate inhibits the interaction of VDR with DNA-cellulose $(8,9)$. Although the DNAcellulose binding characteristics of receptors may accurately predict their functional properties (10-12), recent studies have indicated that the interaction of VDR with DNA-cellulose may not be as specific as previously predicted $(13,14)$. Therefore, the role of the VDR-DNA interaction in calcitriol resistance is better evaluated using natural VDREs. In these experiments, we demonstrate that VDR extracted from rats with renal failure shows impaired binding to a VDRE. In addition, this effect is recapitulated by incubation of normal VDR with a uremic plasma ultrafiltrate. Furthermore, the uremic plasma ultrafiltrate impairs the ability of VDR to activate target genes in a transfection system.

\section{Methods}

Preparation of HPLC-fractionated normal and uremic ultrafiltrates

Uremic plasma ultrafiltrates were obtained from chronic hemodialysis patients. Patients were dialyzed with $1.3 \mathrm{~m}^{2}$ Polysulfone membranes. The ultrafiltrates were collected at the beginning of dialysis from the effluent side of the Polysulfone membrane. Normal pooled plasma was treated identically. Ultrafiltrates were aliquoted into $2-\mathrm{ml}$ fractions, and each 2-ml fraction was subjected to ultrafiltration through a Centrifree ${ }^{\mathrm{TM}}$ filter (Amicon Division, W. R. Grace \& Co., Danvers, MA). Both normal and uremic ultrafiltrates were fractionated by semipreparative HPLC on a RSil $\mathrm{C}_{18}, 10-\mu \mathrm{m}$ column (length $25 \mathrm{~cm}$, inner diameter $10 \mathrm{~mm}$ ) into 13 distinct fractions which were lyophilized as described previously (15). Fractions 4 and $6-13$ of the uremic ultrafiltrate, which contain potent inhibitors of calcitriol action, were combined and used for the following studies. Identical fractions of the normal ultrafiltrate were used as a control. These HPLC fractions excluded salts and glucose. The fractionated normal and uremic ultrafiltrates had identical $\mathrm{pHs}$ of 6.3 when dissolved in distilled water.

\section{Preparation of intestinal VDR}

Male Sprague-Dawley rats weighing $200 \mathrm{~g}$ were fed Purina rat chow containing $1.0 \% \mathrm{Ca}, 0.8 \% \mathrm{P}$, and $4.5 \mathrm{IU}$ vitamin $\mathrm{D} / \mathrm{g}$. Animals received $100 \mathrm{ng}$ of calcitriol intravenously for two consecutive days to enhance receptor concentration. Rats were decapitated, and the initial $20 \mathrm{~cm}$ of 
small intestine distal to the pylorus (duodenum and portion of jejunum) was removed and flushed with ice-cold $\mathrm{Ca} / \mathrm{Mg}$-free phosphate $(6.6 \mathrm{mM}$ $\mathrm{Na}_{2} \mathrm{HPO}_{4}, 250 \mathrm{IU} / \mathrm{ml}$ Trasylol, and $1.5 \mathrm{mM} \mathrm{KH} \mathrm{PO}_{4}$ )-buffered saline (CMF-PBS). The mucosal cells were scraped from the serosa, washed 3 times in $20 \mathrm{vol}$ of CMF-PBS and centrifuged at $200 \mathrm{~g}$ for $5 \mathrm{~min}$ after each washing. The tissue was homogenized in a Polytron in 20 vol (wt/ vol) of buffer consisting of $300 \mathrm{mM} \mathrm{KCl}, 200 \mu \mathrm{g} / \mathrm{ml}$ soybean trypsin inhibitor, $10 \mathrm{mM}$ Tris- $\mathrm{HCl}$ ( $\mathrm{pH} 7.4$ ), $1 \mathrm{mM}$ EDTA, and $5 \mathrm{mM}$ dithiothreitol (KTED) (16). Cellular protein was prepared by centrifugation at $100,000 \mathrm{~g}$ for $45 \mathrm{~min}$ at $0-4^{\circ} \mathrm{C}$. Cellular protein concentration was determined by the Bradford method (17).

\section{Measurement of intestinal VDR concentration}

We have previously determined the binding characteristics of intestina VDR prepared in an identical manner (9). Therefore, onily the $N_{\max }$ of receptor (total concentration of binding sites) was assessed in these experiments. This was accomplished by incubating the cellular protein for $3 \mathrm{~h}$ at $0-4^{\circ} \mathrm{C}$ with a saturating concentration of $\left[{ }^{3} \mathrm{H}\right]$ calcitriol $(5 \mathrm{nM}$, $1 \alpha, 25\left[26,27-{ }^{3} \mathrm{H}\right](\mathrm{OH})_{2} \mathrm{D}_{3}$, specific activity $160 \mathrm{Ci} / \mathrm{mmol}$; New England Nuclear, Boston, MA) in the presence or absence of a 100-fold excess of nonradiolabeled calcitriol. Bound hormone was separated from free hormone by adsorption of free hormone to dextran-coated charcoal (0.2\% dextran, $2.0 \%$ charcoal in $10 \mathrm{mM}$ Tris- $\mathrm{HCl}, 1.0 \mathrm{mM}$ EDTA, $\mathrm{pH}$ 7.4) for $15 \mathrm{~min}$ on ice, followed by centrifugation at $1,600 \mathrm{~g}(9)$. The cellular protein concentration was $2.7 \mathrm{mg} / \mathrm{ml}$, and total concentration of calcitriol binding sites was $615 \mathrm{fmol} / \mathrm{mg}$ protein. This cellular protein was used for the following studies.

\section{Electrophoretic mobility shift assay (EMSA) of VDR incubated with normal or uremic ultrafiltrate}

\section{VDR BINDING TO THE OSTEOCALCIN VDRE}

A 36-bp synthetic oligonucleotide encompassing the rat osteocalcin gene VDRE (base pairs -459 to -432 with CTAG overhangs [18]) was labeled by a fill-in reaction using the Klenow fragment of DNA polymerase $I$ and $\left[\alpha-{ }^{32} \mathrm{P}\right] \mathrm{dCTP}$. The labeled DNA probe was purified on a Sephadex G-50 column.

Intestinal cellular proteins ( $15 \mu \mathrm{l}$ or $\sim 40 \mu \mathrm{g}$ cellular protein) were incubated with $1 \mu \mathrm{M}$ nonradiolabeled calcitriol for $1 \mathrm{~h}$ at room temperature. The cellular proteins were then incubated for another hour with HPLC-fractionated normal (N-UF) or uremic (U-UF) ultrafiltrate at final concentrations of $0,30,60$, and $100 \%$ ( $n=6$ for each concentration) (since the ultrafiltrates were lyophilized to dryness and reconstituted in distilled water to fivefold of the original plasma concentration, achieving a final ultrafiltrate concentration of $100 \%$ required $4 \mu \mathrm{l}$ of redissolved ultrafiltrate per $20 \mu \mathrm{l}$ of incubation). Thereafter, the protein extracts were incubated for another $10 \mathrm{~min}$ in $35 \mu \mathrm{l}$ mobility shift reaction buffer containing $5 \mathrm{mM}$ Tris, $15 \mathrm{mM}$ Hepes, $3.5 \mathrm{mM} \mathrm{MgCl}_{2}, 5 \mathrm{mM}$ EDTA, $10 \%$ glycerol, $0.1 \%$ Tween $20,5 \mathrm{mM}$ dithiothreitol, $0.15 \mu \mathrm{g}$ poly(dI$\mathrm{dC}$ ), and $100 \mathrm{mM} \mathrm{KCl}, \mathrm{pH} 7.9$ (14). Incubations that contained 100\% HPLC-fractionated normal or uremic ultrafiltrates had identical final $\mathrm{pHs}$ of 7.5. At the end of this incubation, $\sim 15,000 \mathrm{cpm}$ of radiolabeled osteocalcin VDRE probe was added in each mobility shift reaction mixture. The reaction mixtures were gently vortexed, incubated for another $10 \mathrm{~min}$, and electrophoresed on $4 \%$ nondenaturing polyacrylamide gels at $100 \mathrm{~V}$ for $\sim 3 \mathrm{~h}$. The mobility shift running buffer contained $50 \mathrm{mM}$ Tris, $380 \mathrm{mM}$ glycine, and 2 mM EDTA (pH 8.5) (19). The gels were dried and autoradiographed, and each VDR-osteocalcin VDRE complex was quantified by excising the portion of the gel corresponding to its location on the autoradiograph. The radioactivity in each excised gel was determined by liquid scintillation counting. The amount of radiolabeled probe associated with VDR that had been incubated with either normal or uremic ultrafiltrate was expressed as a percentage of control VDR incubated in a buffer solution without ultrafiltrate.

To confirm the specificity of VDR-VDRE complex, the following studies were performed. The cellular proteins were incubated for 20 min with: (a) $10 \mathrm{ng}$ nonradiolabeled VDRE or $10 \mathrm{ng}$ nonspecific DNA (from the chick $\beta$ actin gene); (b) 1 and $9 \mu \mathrm{g}$ of either rat anti-VDR monoclonal antibody 9A7 (20) (Affinity BioReagents, Neshanic Station,
$\mathrm{NJ})$ or normal rat $\mathrm{IgG}$; and (c) 1-h incubation with $5 \mathrm{mM}$ pyridoxal phosphate. ${ }^{32} \mathrm{P}$-Osteocalcin VDRE was added to these mixtures and they were electrophoresed as above for identification of the VDRosteocalcin VDRE complexes.

To evaluate whether uremic ultrafiltrate affected the $K_{\mathrm{d}}$ (dissociation constant) or the $N_{\max }$ (maximal binding capacity) of the VDR-VDRE interaction, EMSAs were analyzed by Scatchard analysis. Intestinal cellular proteins $(15 \mu \mathrm{l})$ were incubated with $1 \mu \mathrm{M}$ calcitriol and $100 \%$ normal or uremic ultrafiltrate as above. The cellular proteins were then incubated with increasing concentrations of VDRE probe $(0.125-4.0$ $\mathrm{nM}$ in twofold increments) at room temperature. The incubation mixtures were electrophoresed on $4 \%$ polyacrylamide gels. The dried gel was autoradiographed, and the free and VDR-bound VDREs were quantified by excising the appropriate portions of the gel followed by liquid scintillation counting. The counting efficiency of ${ }^{32} \mathrm{P}$ was determined in each experiment by measuring the counts per minute of free VDREs loaded into the gel and the counts per minute recovered from the gel The loss was $\sim 10-20 \%$, and the calculations were corrected for this loss.

VDR binding affinity for the osteocalcin VDRE in renal failure. Male Sprague-Dawley rats weighing $200 \mathrm{~g}$ were fed Purina rat chow containing $1.0 \% \mathrm{Ca}, 0.8 \% \mathrm{P}$, and $4.5 \mathrm{IU}$ vitamin $\mathrm{D} / \mathrm{g}$. Rats underwent subtotal nephrectomies $(n=5)$ under ether anesthesia. One kidney was removed through a flank incision and two thirds of the other kidney was removed $3 \mathrm{~d}$ later. Control rats $(n=5)$ had sham nephrectomies. They were pair-fed for 1 wk. Control sham operated rats had a serum creatinine of $0.61 \pm 0.01 \mathrm{mg} / \mathrm{dl}$ and nephrectomized rats had a serum creatinine of $1.25 \pm 0.06 \mathrm{mg} / \mathrm{dl}$. Intestinal cellular proteins were prepared and VDR concentrations $\left(N_{\max }\right)$ were measured as above.

Equivalent amounts of $\left[{ }^{3} \mathrm{H}\right]$ calcitriol specific binding proteins (12$15 \mathrm{fmol}$ ) from control and renal failure rats were incubated with increasing concentrations of the osteocalcin VDRE probe $(0.125-4 \mathrm{nM})$ as above. The VDR-osteocalcin VDRE complexes were electrophoresed on $4 \%$ polyacrylamide gels. The dried gels were autoradiographed, and the VDR-VDRE complex and free VDRE bands were quantified by scintillation counting of excised gel slices as described above. Scatchard analysis was used to estimate ${ }^{32} \mathrm{P}$-osteocalcin VDRE specific binding sites and the $K_{\mathrm{d}}$.

\section{VDR BINDING TO THE OSTEOPONTIN VDRE}

A 32-bp synthetic oligonucleotide encompassing the rat osteopontin gene VDRE (bp -761 to -738 plus GATC overhangs [21]) was labeled by a fill-in reaction and used as a probe in a series of EMSAs. The initial experiments were performed as described for the osteocalcin probe and used rat intestinal extracts, N-UF and U-UF, as indicated. In addition, in some studies the intestinal extract was preincubated for 20 $\mathrm{min}$ at room temperature with either the anti-VDR mAb or an antiretinoid X receptor ( $R X R$ ) mAb (22) (or appropriate control antibodies) before addition of the radiolabeled DNA

To further evaluate the effect of U-UF, subsequent studies used recombinant human VDR and mouse RXR $\alpha$ purified from Escherichia coli. Full-length VDR and $\mathrm{RXR} \alpha$ proteins were expressed from the vector pMalc2 (New England Biolabs Inc., Beverly, MA). This vector produces a fusion protein of maltose binding protein followed by a cleavage site for Factor $\mathrm{Xa}$ and the recombinant protein. The fusion protein is purified by affinity chromatography on an amylose column and cleaved with Factor Xa. Purification of RXR $\alpha$ using this methodology has been described (22). An identical protocol was.used to purify VDR. The yield of purified VDR fusion protein was $\sim 1 \mathrm{mg} / 500 \mathrm{ml}$ of broth. After cleavage with Factor Xa, analysis by SDS-PAGE and Coomassie blue staining revealed bands of $48 \mathrm{kD}$ (as expected for VDR) and $42 \mathrm{kD}$ (as expected for maltose binding protein) that accounted for $\sim 90 \%$ of the protein staining. The maltose binding protein was not removed since it is not a DNA binding protein. EMSA incubations used $100 \mathrm{ng}$ of RXR $\alpha$ and $250 \mathrm{ng}$ of VDR unless indicated otherwise. Where indicated, receptors were incubated individually for $1 \mathrm{~h}$ at $15^{\circ} \mathrm{C}$ with various concentrations $(30,60$, and $100 \%)$ of N-UF or U-UF (or buffer) Incubations were performed at $15^{\circ} \mathrm{C}$ because the VDR was found to 
lose some DNA binding activity after incubation in buffer alone at room temperature for $1 \mathrm{~h}$. Thereafter, these receptor preparations were added to EMSA incubations as described above. Since the 35- $\mu$ l EMSA incubations required only $1-2 \mu \mathrm{l}$ of ultrafiltrate-incubated VDR and RXR $\alpha$, the concentration of N-UF or U-UF was diluted 17.5-35-fold during the EMSA incubations.

The following studies were performed to test whether the effect of U-UF on VDR was irreversible. E. coli-derived VDR was incubated for $1 \mathrm{~h}$ at $15^{\circ} \mathrm{C}$ with $60 \% \mathrm{~N}$-UF or U-UF (or buffer). The receptor mixtures were then diluted 40-fold with iced EMSA binding buffer and concentrated to $50 \mu \mathrm{l}$ by ultrafiltration through a Centricon-30 at $4^{\circ} \mathrm{C}$. These receptors were then used in EMSAs, resulting in a final ultrafiltrate concentration of only $\sim 0.4 \%$ during the EMSA incubations.

\section{Evaluation of uremic ultrafiltrate for proteolytic activity on $V D R$}

$\left[{ }^{35}\right.$ S]Methionine-labeled VDR was produced by in vitro transcription and translation of the human VDR cDNA in rabbit reticulocyte lysate according to the vendor's protocol (Promega, Madison, WI). The translation product had $\sim 30,000 \mathrm{cpm}$ of trichloroacetic acid-precipitable protein $/ \mu \mathrm{l}$ of reaction volume. A series of incubations was performed to determine whether uremic ultrafiltrate might contain a protease that degrades VDR. $6 \mu \mathrm{l}$ of ${ }^{35} \mathrm{~S}$-labeled translation product was incubated for $1 \mathrm{~h}$ at room temperature with $100 \%$ normal ultrafiltrate, $100 \%$ uremic ultrafiltrate, or buffer alone in a total volume of $30 \mu \mathrm{l}$. One sixth of each incubation was then analyzed by SDS-PAGE and fluorography.

\section{Immunoblots of VDR extracted from normal and renal failure rats}

$30 \mu \mathrm{g}$ of intestinal cellular protein (containing VDR) from one control and one renal failure rat was subjected to electrophoresis on a $10 \%$ polyacrylamide SDS gel and electrotransferred to a nitrocellulose membrane. VDR was detected using the ECL Western blotting kit per the vendor's (Amersham, Arlington Heights, IL) protocol. The primary antibody was the rat monoclonal anti-VDR antibody clone 9A7 diluted $1: 1,000$, and the secondary antibody was a horseradish peroxidaselinked sheep anti-rat Ig (Amersham) diluted 1:2,000. Autoradiography was for $1 \mathrm{~h}$.

\section{The effect of uremic ultrafiltrate on the calcitriol- dependent expression of a reporter gene in transfected JEG-3 cells}

We have shown previously that JEG-3 cells support the induction of reporter gene expression by calcitriol in the presence of cotransfected VDR (23). An identical transfection protocol was used in these experiments. The human VDR cDNA was expressed from the vector pCDM. The reporter plasmid was derived from pUTKAT3 (21), and contained two copies of the sequence 5'-GATCCACTAGGTCAAGGAGGTCATGGATC ligated $5^{\prime}$ to the basal thymidine kinase promoter driving expression of chloramphenicol acetyltransferase (CAT) (pTKD2AA). An internal control plasmid expressing human growth hormone $(\mathrm{GH})$ from the basal thymidine kinase promoter (pTKGH) was used to control for transfection efficiency. Transfections included $4 \mu \mathrm{g}$ of pTKD2AA, 10 ng of pCDMVDR, $1 \mu \mathrm{g}$ of pTKGH, and $6 \mu \mathrm{g}$ of pCDM as filler plasmid per $60-\mathrm{mm}$ Petri dish. Cells were cultured with or without $100 \mathrm{nM}$ calcitriol for $2 \mathrm{~d}$ after transfection. In certain experiments, N-UF or UUF was added for the $2 \mathrm{~d}$ after transfection at a final concentration of up to $50 \%$. Cell lysates were analyzed for CAT activity and media for human GH as described (23). Fold CAT induction is defined as CAT/ human GH for cells cultured with calcitriol divided by $\mathrm{CAT} /$ human $\mathrm{GH}$ for cells cultured without calcitriol.

$\left[{ }^{3} \mathrm{H}\right]$ Calcitriol binding experiments were performed to test whether cell culture in the presence of U-UF altered expression of the recombinant VDR. JEG-3 cells were transfected with pCDMVDR and cultured for $2 \mathrm{~d}$ in the presence of $50 \% \mathrm{~N}$-UF, $50 \% \mathrm{U}-\mathrm{UF}$, or control media. Cell extracts were prepared and used in $\left[{ }^{3} \mathrm{H}\right]$ calcitriol binding experiments as described above. Pilot experiments indicated that transfection with 10

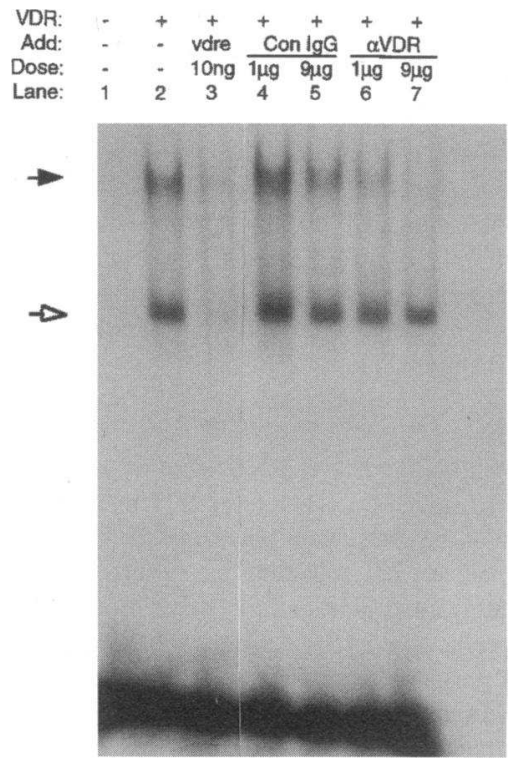

Figure 1. EMSA of the VDR-VDRE complex. Intestinal VDR was incubated with radiolabeled rat osteocalcin VDRE and subjected to polyacrylamide gel electrophoresis. Lane 1 , free radiolabeled VDRE probe; lane 2, two protein-radiolabeled VDRE complexes were detected; lane 3 , addition of $10 \mathrm{ng}$ cold VDRE to the protein-DNA incubation nearly abolished the two protein-radiolabeled DNA complexes; lanes 4 and 5 , incubation with 1 and $9 \mu \mathrm{g}$ control rat IgG had little effect on either protein-DNA complex; lanes 6 and 7, incubation with 1 and $9 \mu \mathrm{g}$ of rat monoclonal anti-VDR antibody inhibited the slower migrating complex (filled arrow), indicating that this complex contained VDR. The faster migrating complex (open arrow) was unaffected by the antibody and therefore presumably did not contain VDR.

ng of pCDMVDR resulted in VDR levels too low to quantify accurately by this method. Therefore, these studies were performed by transfecting $6 \mu \mathrm{g}$ pCDMVDR per 60 -mm Petri dish ( $1 \mu \mathrm{g}$ pTKGH was cotransfected to control for transfection efficiency).

\section{Statistical analysis}

All data are the mean \pm SE. Statistical analysis was performed using the Student's $t$ test and Duncan's multiple range test. A $P$ value $<0.05$ was considered significant.

\section{Results}

\section{EMSA of VDR incubated with normal or uremic ultrafiltrate}

VDR BINDING TO THE OSTEOCALCIN VDRE

Detection of VDR-osteocalcin VDRE complex by EMSA. EMSA experiments to identify the VDR-osteocalcin VDRE complex are illustrated in Figs. 1 and 2. In Fig. 1 it is seen that the intestinal extract forms two distinct complexes with the VDRE probe (lane 2), both of which are quenched by the addition of 100-fold excess of nonradiolabeled VDRE (lane 3). The slower migrating complex, indicated by the solid arrow, was also abolished by incubation with a monoclonal anti-VDR antibody but was minimally affected by incubation with an identical dose of control IgG (compare lane 6 vs. 4 , and 7 vs. 5). mAb 9A7 binds to an epitope (amino acids 89-105) located adjacent to the VDR DNA binding domain (20) and presumably sterically impedes the VDR-VDRE interaction. These studies indicate that this slower migrating complex contains VDR. In contrast, the faster migrating protein-VDRE complex, marked by the open arrow, was unaffected by the anti-VDR antibody and thus presumably did not contain VDR. In addition, Fig. 2 illustrates that incubation of VDR with $5 \mathrm{mM}$ pyridoxal phosphate virtually abolished the VDR-VDRE complex (lane 3). This is in agreement with our previous finding that pyridoxal phosphate completely inhibited VDR binding to DNA-cellulose (24) and 


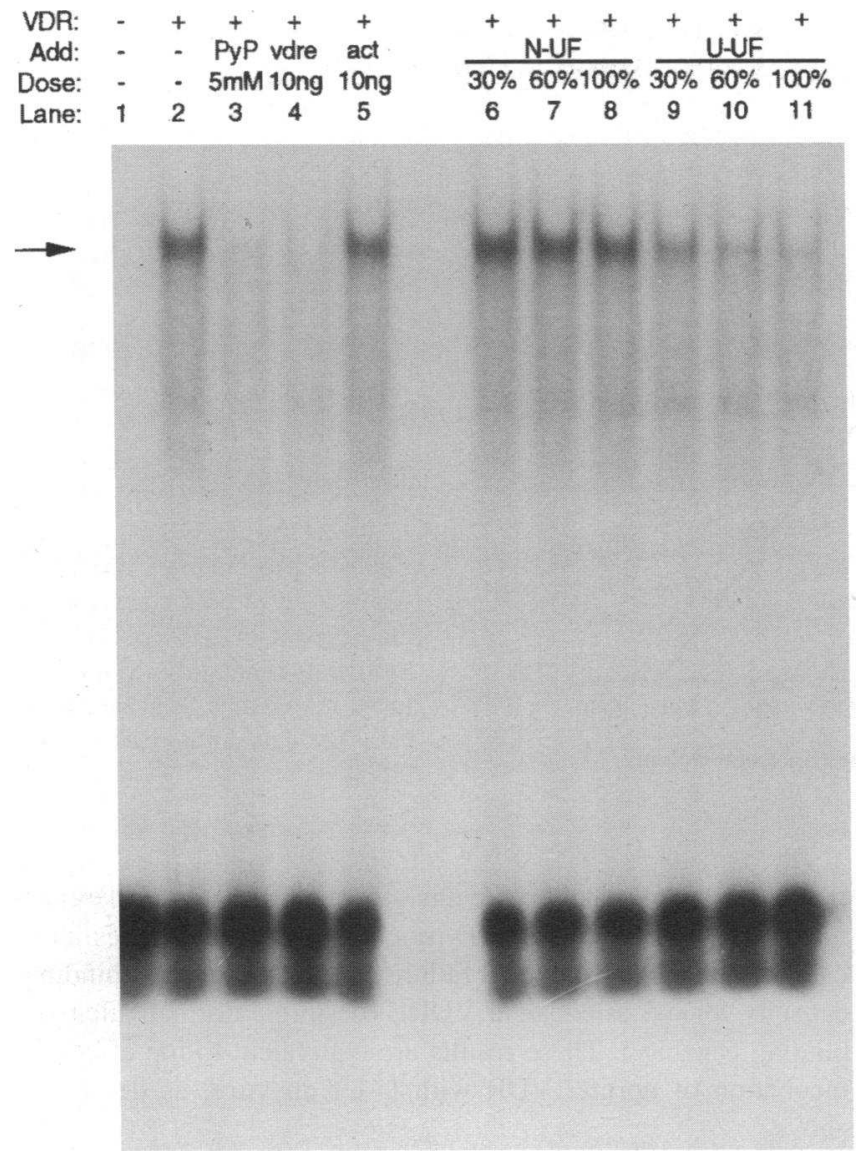

Figure 2. Inhibition of VDR-VDRE complexes by U-UF. Intestinal VDRs were incubated for $1 \mathrm{~h}$ with $0,30,60$, and $100 \%$ of N-UF or UUF and then incubated with radiolabeled VDRE. Lane 1, free radiolabeled VDRE; lane 2, incubation of VDR with radiolabeled VDRE to demonstrate the VDR-VDRE complex; lane 3, addition of pyridoxal phosphate to the mixture abolished the VDR-VDRE complex; lane 4, addition of nonradiolabeled VDRE to the mixture also eliminated the VDR-VDRE complex; lane 5, irrelevant DNA from the chick actin gene did not compete with the VDRE for VDR; lanes $6-8, \mathrm{~N}$-UF did not inhibit the VDR binding to the VDRE; lanes 9-11, U-UF inhibited the VDR-VDRE interaction in a dose-dependent manner.

is similar to the effect of pyridoxal phosphate on the DNA binding of glucocorticoid receptors (25). Although the VDRVDRE complex was quenched by the addition of nonradiolabeled VDRE (Fig. 2, lane 4), addition of irrelevant DNA did not influence this complex (lane 5). Thus, Figs. 1 and 2 together identify the slower migrating band as representing a specific VDR-VDRE complex.

The effect of uremic ultrafiltrate on the binding of VDRs to the osteocalcin VDRE. The effect of uremic ultrafiltrate on the VDR-VDRE interaction is depicted in Fig. 2. As shown in lanes $6-8$, the normal ultrafiltrate, even up to $100 \%$, did not impair the VDR-VDRE complex. However, uremic ultrafiltrate inhibited the interaction of the VDR with the osteocalcin VDRE in a dose-related manner (lanes 9-11). These data are quantified in Fig. 3.

To determine whether this effect of uremic ultrafiltrate was due to a change in $N_{\max }$ or $K_{\mathrm{d}}$, EMSA incubations were performed with normal or uremic ultrafiltrate and increasing doses of VDRE (0.125-4 $\mathrm{nM})$, and the appropriate bands were then

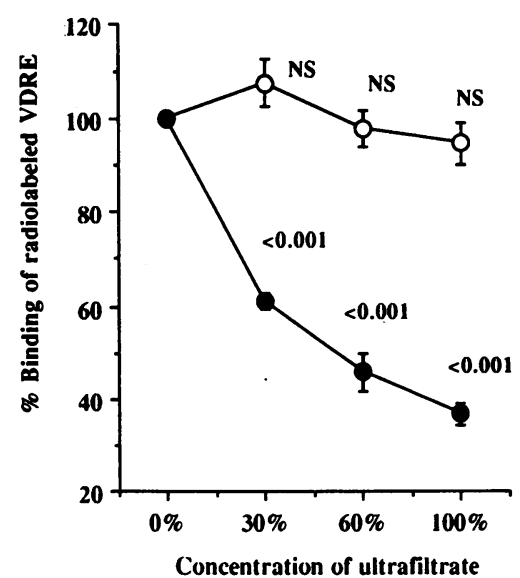

Figure 3. Percent inhibition of VDR binding to the VDRE by increasing concentrations of N-UF (open circles) and U-UF (filled circles) $(0,30,60$, and $100 \% ; n=6$ for each concentration). The results are derived from Fig. 2 and similar studies.

subjected to Scatchard analysis. As depicted in Figs. 4 and 5, the effect of uremic ultrafiltrate was entirely accounted for by a decrease in $N_{\max }$. The VDR incubated with uremic ultrafiltrate had an $N_{\max }$ of $211 \pm 22 \mathrm{fmol} / \mathrm{mg}$ protein, which was significantly lower than that of the VDR incubated with normal ultrafiltrate (442 $\pm 24 \mathrm{fmol} / \mathrm{mg}$ protein, $n=5, P<0.001$ ). However, the estimated values of $K_{\mathrm{d}}$ were not different between the VDR incubated with normal and uremic ultrafiltrate $(2.88 \pm 0.41 \mathrm{nM}$ vs. $3.32 \pm 0.33 \mathrm{nM}$, respectively, $P>0.05$ ).

Studies with radiolabeled recombinant VDR were performed to exclude the possibility that the effect of uremic ultrafiltrate on DNA binding was due to proteolytic degradation of the VDR. ${ }^{35}$ S-labeled VDR was incubated with $100 \% \mathrm{~N}-\mathrm{UF}$, $100 \% \mathrm{U}-\mathrm{UF}$, or buffer alone for $1 \mathrm{~h}$ at room temperature and then analyzed by SDS-PAGE (Fig. 6). The pattern of translation products was identical for all incubations and was identical to that of freshly translated ${ }^{35} \mathrm{~S}$-labeled VDR. The major translation product was $\sim 45 \mathrm{kD}$, and several minor translation products

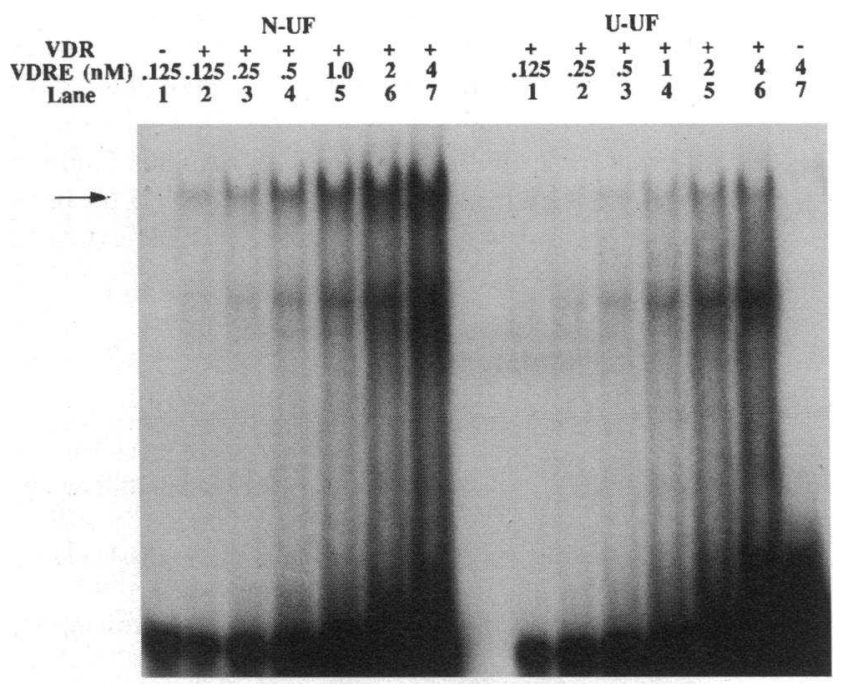

Figure 4. EMSA of VDR-VDRE complex formation in the presence of N-UF or U-UF. Intestinal VDRs were incubated for $1 \mathrm{~h}$ with $100 \%$ N-UF (left) or $100 \%$ U-UF (right) and then increasing concentrations of radiolabeled VDRE $(0.125-4 \mathrm{nM})$ were added. Lane $1(0.125 \mathrm{nM})$ of the left panel (N-UF) and lane $7(4 \mathrm{nM})$ of the right panel (U-UF) were free probes. The data were subjected to Scatchard analysis (see Fig. 5). 

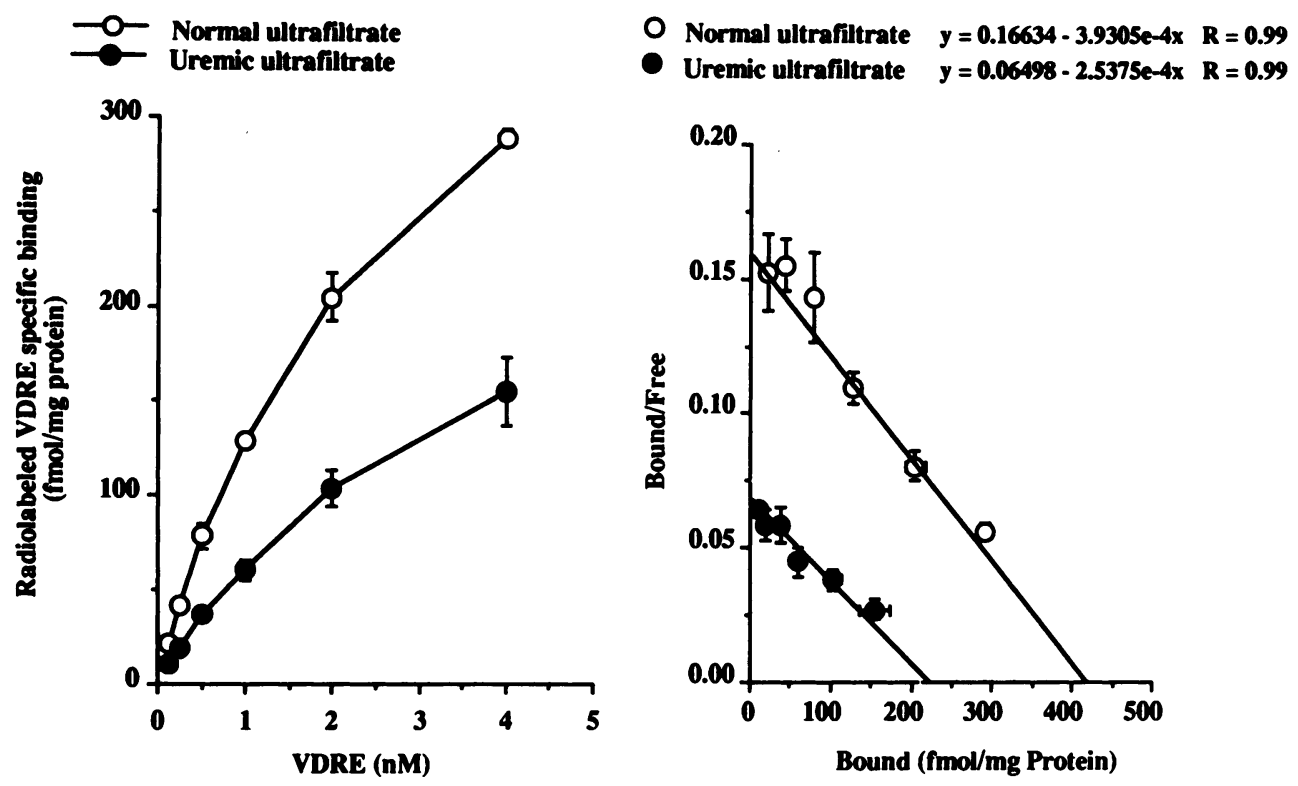

Figure 5. The binding characteristics of VDR-VDRE complexes in the presence of $100 \%$ normal $(n$ $=5)$ and uremic $(n=5)$ ultrafiltrates analyzed by Scatchard analysis. The data are derived from Fig. 4.

also were observed. These data exclude proteolytic activity as an explanation for the impaired VDR-VDRE interaction after incubation of VDR with uremic ultrafiltrate.

Binding of VDR from normal and renal failure rats to the osteocalcin VDRE. The binding affinity of the VDR for the osteocalcin VDRE was measured in intestinal extracts from control and renal failure rats. Equivalent quantities of $\left[{ }^{3} \mathrm{H}\right]-$ calcitriol specific binding activity of normal and renal failure rats were incubated with increasing concentrations of VDRE probe $(0.125-4 \mathrm{nM})$ as shown in Figs. 7 and 8 (normal, 17.7 $\mu \mathrm{g}$ protein $=12.3 \mathrm{fmol}\left[{ }^{3} \mathrm{H}\right]$ calcitriol specific binding activity; renal failure, $18.3 \mu \mathrm{g}$ protein $=12.3 \mathrm{fmol}\left[{ }^{3} \mathrm{H}\right]$ calcitriol specific binding activity). Scatchard analysis was used to quantify ${ }^{32} \mathrm{P}$ VDRE specific binding. VDR obtained from renal failure rats had significantly lower binding capacity for the VDRE $\left(N_{\max }=\right.$ $295 \pm 78 \mathrm{fmol} / \mathrm{pmol}\left[{ }^{3} \mathrm{H}\right]$ calcitriol binding protein, $n=5$ ) when compared with that of control rats $\left(543 \pm 55 \mathrm{fmol} / \mathrm{pmol}\left[{ }^{3} \mathrm{H}\right]-\right.$ calcitriol binding protein, $n=5, P<0.05)$. However, the $K_{\mathrm{d}}$ was not different between the two groups of animals (control, $4.07 \pm 0.54 \mathrm{nM}$ vs. renal failure, $4.75 \pm 1.41 \mathrm{nM}, n=5$ for both, $P>0.05$ ) (Fig. 8). Immunoblot studies of the VDR extracted

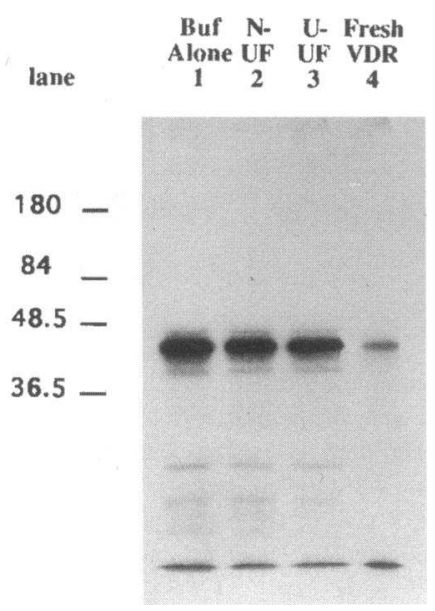

Figure 6. Lack of proteolytic activity of uremic ultrafiltrate on VDR. Recombinant ${ }^{35} \mathrm{~S}$-VDR was produced by translation in reticulocyte lysate and then incubated for $1 \mathrm{~h}$ at room temperature with buffer alone (lane 1 ), $100 \%$ normal ultrafiltrate (lane 2), or $100 \%$ uremic ultrafiltrate (lane 3). Products were analyzed by SDS-PAGE and autoradiography. Lane 4 represents freshly translated ${ }^{35} \mathrm{~S}-\mathrm{VDR}, 25 \%$ of the amount of protein as loaded in lanes $1-3$. from control and renal failure rats showed that they had identical molecular masses of $\sim 44 \mathrm{kD}$ (not shown). These studies indicate that the VDR from renal failure rats has a decreased binding capacity for the osteocalcin VDRE (despite a normal calcitriol binding capacity). These results are equivalent to the effect of incubation of normal VDR with U-UF in vitro, as described above.

VDR BINDING TO THE OSTEOPONTIN VDRE

The effect of uremic ultrafiltrate on the VDR-RXR-osteopontin $V D R E$ interaction. Incubation of intestinal extracts from normal
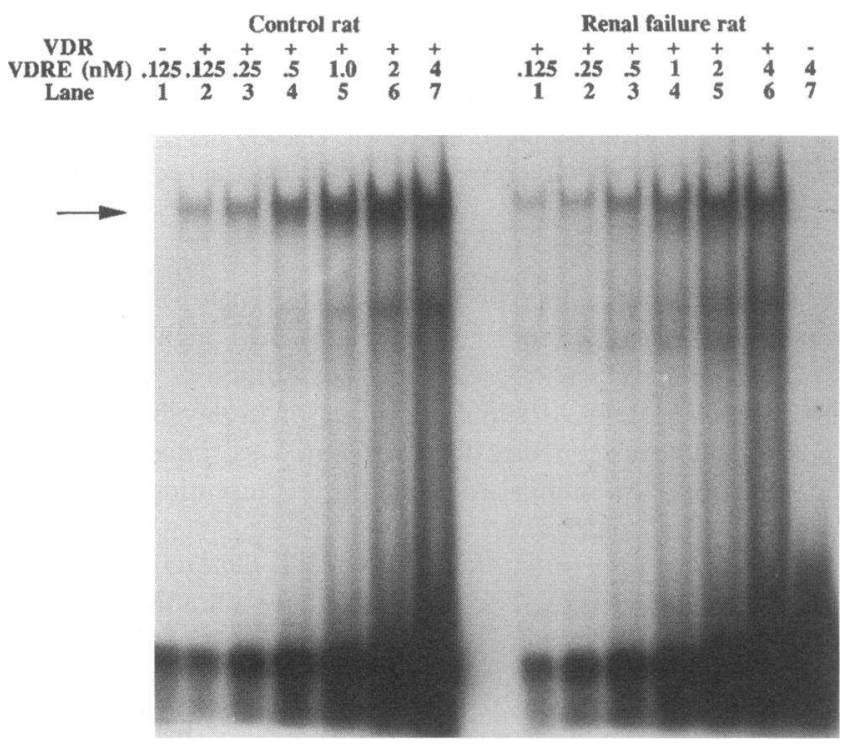

Figure 7. EMSA of VDR-VDRE complex formation with VDR from normal and renal failure rats. $12.3 \mathrm{fmol}$ of $\left[{ }^{3} \mathrm{H}\right]$ calcitriol specific binding proteins from normal $(l e f t)$ and renal failure $(r i g h t)$ rats was incubated with increasing concentrations of radiolabeled VDRE $(0.125-4 \mathrm{nM})$. Lane $l(0.125 \mathrm{nM})$ of the left panel (Control rat) and lane $7(4 \mathrm{nM})$ of the right panel (Renal failure rat) were free probes. The data were subjected to Scatchard analysis (see Fig. 8). 


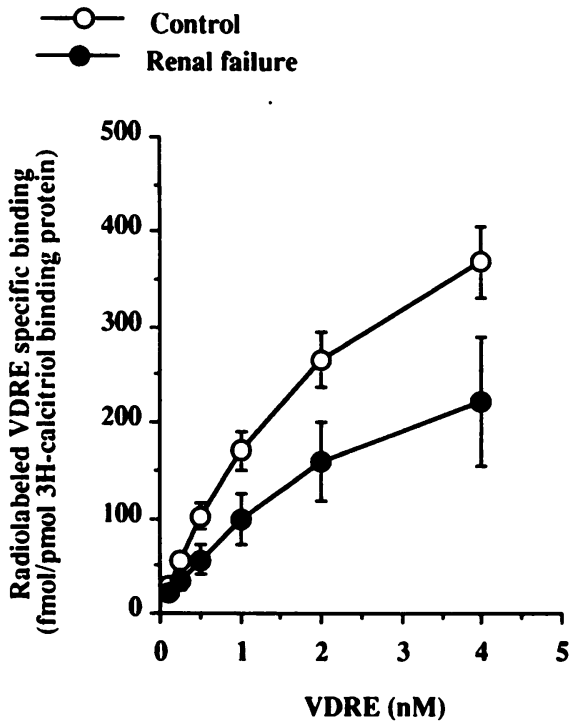

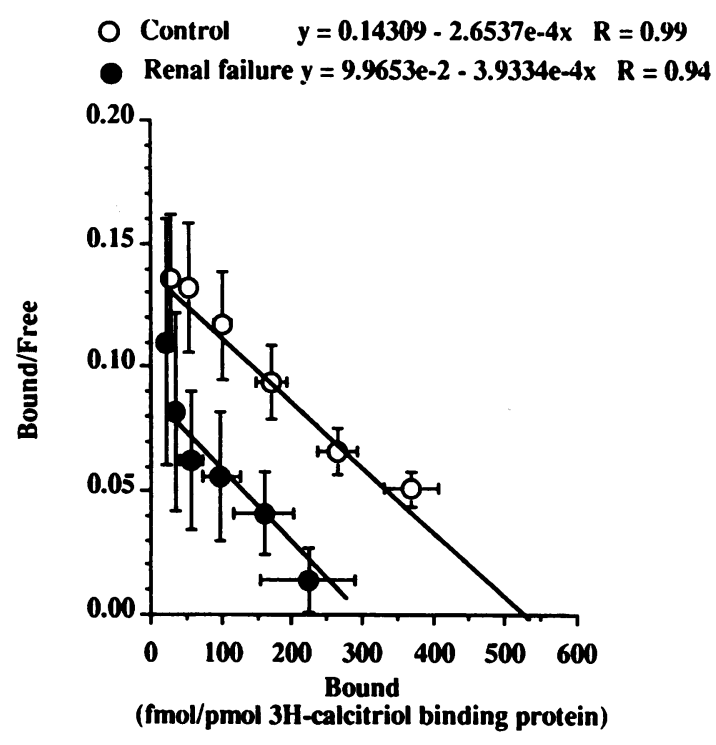

Figure 8 . The binding characteristics of VDR-VDRE complexes of normal $(n=5)$ and renal failure rats $(n=5)$ analyzed by Scatchard analysis. The data are derived from Fig. 7. rats with the osteopontin VDRE led to the formation of two protein-DNA complexes as analyzed by EMSA (Fig. 9, lane 2). The addition of monoclonal antibodies to VDR (lane 3) or RXR (lane 5) indicated that the faster migrating complex (solid arrow) represents a VDR-RXR heterodimer on the DNA. The nature of the slower migrating complex is unknown. It was unaffected by the RXR antibody and thus presumably does not contain RXR. The intensity of this complex was modestly diminished by the anti-VDR antibody. Therefore, it might contain VDR in a conformation that is only partially accessible to the antibody - perhaps as a homodimer, for example. Alternatively, the modest effect of the anti-VDR monoclonal antibody could represent crossreactivity with another DNA binding protein. Since we find that recombinant VDR does not bind to this DNA as a homodimer (see below), we favor the latter interpretation.

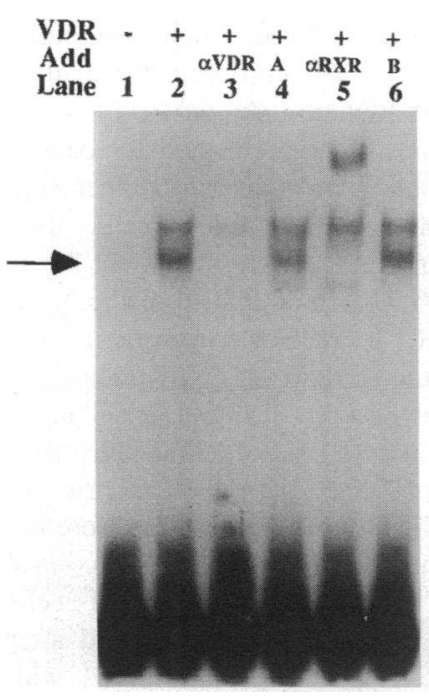

Figure 9. EMSA of intestinal VDR binding to the osteopontin VDRE. Rat intestinal extracts were incubated with radiolabeled osteopontin VDRE and analyzed by EMSA. Lane 1 , free probe; lane 2, intestinal extract forms two protein-radiolabeled osteopontin VDRE complexes; lanes 3 and 4 , the faster migrating complex is inhibited by preincubation with a rat monoclonal anti-VDR antibody $(\alpha$ VDR, of control rat $\operatorname{IgG}(A$, lane 4$)$; lanes 5 and 6 , the faster migrating complex is supershifted by preincubation with a mouse monoclonal anti-RXR antibody $(\alpha R X R)$, but not by an equal dose of control mouse monoclonal IgG (anti-LDL receptor, $B$, lane 6). lane 3$)$, but not by an equal dose
Fig. 10 shows that incubation of the intestinal extract with U-UF resulted in decreased VDR-RXR binding to the probe (lanes 7-9), whereas N-UF was without effect (lanes 4-6). These results are similar to those obtained with the osteocalcin VDRE. In addition, it should be noted that U-UF also inhibited formation of the unidentified slower migrating protein-DNA complex.

The above results could indicate an effect of U-UF on VDR, RXR, or both. To address this we performed studies with recombinant VDR and RXR $\alpha$ purified from $E$. coli. Fig. 11 illustrates that neither recombinant protein alone formed a detectable complex with the osteopontin VDRE probe (lanes 2 and 3). However, addition of VDR plus RXR $\alpha$ resulted in the formation of a heterodimer complex with the probe (lane 4), consistent with the results of Fig. 9 using intestinal extracts. This VDR-RXRVDRE complex was quenched by the addition of 100-fold excess of nonradiolabeled VDRE (lane 5), but not by the addition of 100-fold excess of actin DNA (lane 6 ), as expected for a specific protein-DNA complex.

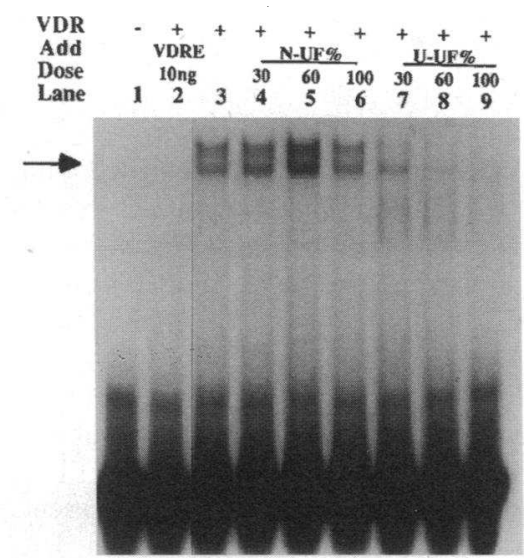

Figure 10. Effect of UUF on the binding of intestinal VDR to the osteopontin VDRE. Lane 1, free labeled probe; lane 2 , intestinal VDR failed to bind to the labeled VDRE in the presence of $10 \mathrm{ng}$ ( 100-fold) unlabeled VDRE; lane 3, intestinal VDR-VDRE complex (arrow); lanes 4-6, preincubation of VDRs with various concentrations of N-UF: lanes 7-9, preincubation of VDRs with various concentrations of U-UF. The U-UF weakened the VDR binding to the labeled VDRE. 


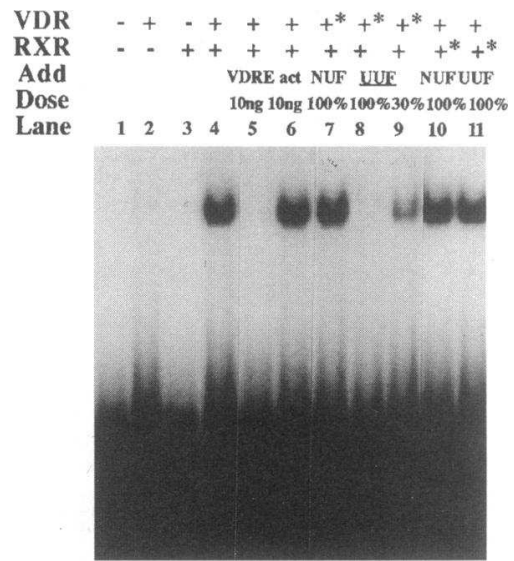

Figure 11. Effect of UUF on the binding of $E$. coli-derived VDR$\mathrm{RXR} \alpha$ heterodimers to the osteopontin VDRE. Lane 1 , free radiolabeled osteopontin VDRE probe; lane 2 , incubation of $E$. coli-derived VDR with labeled VDRE did not result in a detectable protein-DNA complex; lane 3, incubation of $E$. coli-derived RXR $\alpha$ with labeled VDRE did not result in a detectable protein-DNA complex;

lane 4, a mixture of VDR, RXR $\alpha$, and the labeled VDRE resulted in formation of a heterodimer-DNA complex; lane 5, 100-fold excess nonradiolabeled VDRE quenched the heterodimer-probe complex; lane 6,100 -fold excess nonradiolabeled $\beta$ actin did not quench the heterodimer-probe complex; lane 7, preincubation of VDR with N-UF did not impair VDR-RXR binding to the labeled VDRE; lanes 8 and 9 , preincubation of VDR with U-UF inhibited VDR-RXR binding to the VDRE; lanes 10 and 11 , preincubation of RXR with N-UF or U-UF did not inhibit VDR-RXR binding to the VDRE. The asterisks denote receptors that were preincubated with N-UF or U-UF.

Recombinant VDR or RXR $\alpha$ was separately preincubated with N-UF or U-UF for $1 \mathrm{~h}$ and then used in an EMSA with the other receptor and the osteopontin VDRE as the probe. Preincubation of VDR with U-UF inhibited formation of the VDR-RXR-DNA complex in a dose-dependent manner (Fig. 11 , lanes 8 and 9), whereas N-UF had no effect even at $100 \%$ (lane 7). In contrast, preincubation of RXR with even $100 \% \mathrm{U}$ UF failed to impair formation of the VDR-RXR-VDRE complex (lane 11). These results indicate that the ability of U-UF to impair the formation of a VDR-RXR-DNA complex is due to an effect on the VDR.

Experiments were performed to assess whether the effect of U-UF on the VDR is irreversible. After a 1-h incubation of $E$. coli-derived VDR with $60 \%$ U-UF or N-UF, the mixtures were diluted 40-fold in iced EMSA binding buffer and then concentrated back to their original volumes by ultrafiltration through a Centricon-30. Since the U-UF and N-UF were originally prepared by ultrafiltration through a membrane with a molecular weight cutoff of $\sim 10,000$, it can be assumed that the uremic toxin(s) in U-UF will readily pass through a Centricon-30 (30,000 molecular weight cutoff). After concentration through the Centricon-30, the VDRs were used in an EMSA with the osteopontin VDRE as the probe. The final concentration of U-UF or N-UF in the EMSA incubation was $\sim 0.4 \%$. As seen in Fig. 12, The VDR that had been preincubated with U-UF (lane 7) still was deficient in DNA binding relative to the VDR that had been preincubated with N-UF (lane 6 ) or buffer (lane 5). As an additional control, we found that incubating the VDR in $0.4 \%$ (lane 3) or 5\% (lane 4) U-UF and maintaining the same respective concentrations of U-UF throughout the incubations in the DNA binding reaction were not sufficient to impair VDR-VDRE binding. This indicates that the inhibitory effect seen in lane 7 results from preexposure of the VDR to $60 \%$ U-UF, not to trace amounts of residual U-UF present during the DNA binding incubation. It should be noted that

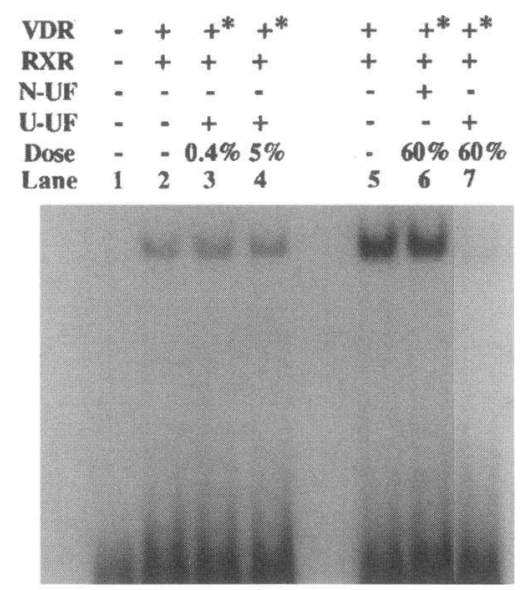

Figure 12 . The inhibitory effect of U-UF on VDR is irreversible. E. coliderived VDR was incubated for $1 \mathrm{~h}$ with $60 \%$ U-UF or N-UF, then diluted 40-fold and reconcentrated by ultrafiltration through a Centricon30 to remove ultrafiltrates. This material was then used in a proteinDNA binding assay with E. coli-derived RXR and the ${ }^{32} \mathrm{P}$-osteopontin VDRE. The final concentration of ultrafiltrate in the DNA incubations

was $\sim 0.4 \%$. Lane 1 , probe only; lane $2,0.5 \mu \mathrm{g}$ VDR incubated for 1 $\mathrm{h}$ in buffer solution before addition to the EMSA incubation; lanes 3 and 4, preincubation of $0.5 \mu \mathrm{g}$ VDR with 0.4 and $5 \%$ of U-UF for $1 \mathrm{~h}$ and inclusion of the same dose of U-UF in the final EMSA incubation did not impair heterodimer-DNA binding; lane 5 (control), $1.25 \mu \mathrm{g}$ VDR and RXR form a heterodimer-VDRE complex; lanes 6 and 7 , preincubation of $1.25 \mu \mathrm{g}$ VDR with $60 \% \mathrm{U}-\mathrm{UF}$ and ultrafiltration down to $0.4 \%$ U-UF in the final EMSA incubation inhibited heterodimerDNA binding relative to preincubation with N-UF.

lanes 5-7 used 2.5-fold more receptor than lanes 2-4 in order to enhance the sensitivity for detecting a VDR-RXR-DNA complex in lane 7. These studies are consistent with the notion that U-UF irreversibly modifies the VDR and therefore does not have to be present during the DNA binding reaction to inhibit the VDR-VDRE interaction.

The effect of uremic ultrafiltrate on the calcitriol-dependent expression of CAT activity in transfected JEG-3 cells. JEG-3 cells were transiently transfected with a VDR expression plasmid, a VDRE-containing CAT reporter plasmid, and an internal control plasmid expressing human $\mathrm{GH}$. In the absence of transfected VDR, calcitriol induction of CAT was $<1.5$-fold (data not shown). However, after cotransfection with the expression vector pCDMVDR, calcitriol induced CAT activity 23fold (Fig. 13, Control). Addition of $50 \%$ N-UF did not alter the CAT induction, whereas 33 and 50\% U-UF inhibited calcitrioldependent CAT activity in a dose-dependent manner (Fig. 13). Furthermore, this effect of U-UF was on the calcitriol-induced activity, not the basal CAT activity. In addition, U-UF had no effect on human GH expression (data not shown).

$\left[{ }^{3} \mathrm{H}\right]$ Calcitriol binding studies were performed to exclude the possibility that this effect of U-UF was due to decreased expression of the recombinant VDR. JEG-3 cells were transfected with pCDMVDR and then were cultured for $2 \mathrm{~d}$ in the presence of $50 \%$ N-UF, $50 \%$ U-UF, or control media. Cells were harvested and $0.3 \mathrm{M} \mathrm{KCl}$ extracts were used in $\left[{ }^{3} \mathrm{H}\right]-$ calcitriol binding studies. Extracts from the VDR-transfected cells cultured with U-UF bound $0.13 \pm 0.01 \mathrm{pmol}\left[{ }^{3} \mathrm{H}\right]$ calcitriol/ mg protein, compared with $0.11 \pm 0.01 \mathrm{pmol}\left[{ }^{3} \mathrm{H}\right]$ calcitriol for cells cultured with $\mathrm{N}$-UF and $0.10 \pm 0.02$ pmol $\left[{ }^{3} \mathrm{H}\right]$ calcitriol for cells cultured with control media alone. These results were not altered by normalizing to human $\mathrm{GH}$ expression as a control for transfection efficiency. $\left[{ }^{3} \mathrm{H}\right] \mathrm{Calcitriol}$ binding of cells transfected with empty vector was $<1 \%$ that observed after transfection with pCDMVDR. These results combined with 


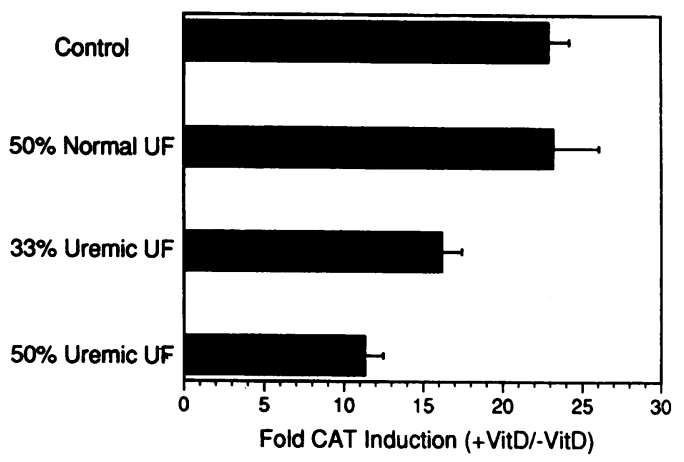

Figure 13. The effect of uremic ultrafiltrate on the expression of calcitriol-induced CAT activity in transfected JEG-3 cells. JEG-3 cells were transfected with a VDR expression vector, a CAT reporter plasmid driven by a calcitriol responsive promoter, and a human $\mathrm{GH}$-expressing reporter as an internal control. Cells were incubated with 0,33 , or $50 \%$ N-UF or U-UF, in each case with or without $100 \mathrm{nM}$ calcitriol, for 48 h. Fold CAT induction is defined as CAT/human GH for cells cultured with calcitriol divided by CAT/human GH for cells cultured without calcitriol. Results are the mean \pm SE for four independent transfections, except for $33 \%$ U-UF, which represents two independent transfections.

those of Fig. 13 indicate that U-UF impairs the ability of calcitriol to induce the expression of target genes, but that this effect is not due to a reduction in the expression of VDRs. Overall the data are consistent with the hypothesis that U-UF impairs VDR-DNA interactions within the cell, thereby limiting the calcitriol response.

\section{Discussion}

We have demonstrated previously that uremic ultrafiltrate inhibited the interaction of VDR with DNA-cellulose $(8,9)$. Although the binding of VDR to DNA-cellulose may not directly measure the interaction of VDR with biologically relevant DNA sequences, several studies have demonstrated that the binding properties of VDR to DNA-cellulose accurately reflect the functional characteristics of the VDR (10-12). However, since the binding to nonspecific DNA may be mechanistically distinct from that to specific VDREs, serious consideration must be given to the possibility that measurement of nonspecific DNA binding may not always be an accurate surrogate for specific DNA binding. Since the VDREs of the osteocalcin and osteopontin genes have been well characterized $(21,26,27)$, it is now possible to perform VDR-DNA binding studies with these specific genes sequences. Thus, the present studies were undertaken to characterize the effect of uremic toxins on the binding properties of the VDR to the osteocalcin and osteopontin VDREs.

In our previous studies (9) we showed that VDR incubated for $3 \mathrm{~h}$ with uremic ultrafiltrate eluted from a DNA-cellulose column as a single peak at a lower ionic strength than the receptor incubated with normal ultrafiltrate. The interaction of receptor with DNA-cellulose weakened as the concentration of uremic ultrafiltrate increased, and only a single peak of VDR eluted at each concentration of uremic ultrafiltrate. Thus, receptors incubated with uremic ultrafiltrate behaved as a homogeneous pool of proteins whose binding to DNA-cellulose gradually weakened as the concentration of uremic ultrafiltrate increased. In this study, the incubation of receptor with uremic ultrafiltrate for $1 \mathrm{~h}$ at room temperature resulted in a $>50 \%$ loss of specific DNA binding sites, but the remaining receptors appeared to function properly as they retained a normal $K_{\mathrm{d}}$ for the osteocalcin VDRE. This suggests that the VDR incubated with uremic ultrafiltrate consists of two distinct populations of molecules - those incapable of binding specific DNA and those with normal specific DNA binding properties. This conclusion appears to contrast with the above DNA-cellulose data. The reason for this discrepancy is not clear, although several possibilities should be considered. The first is that binding data for DNA-cellulose do not accurately predict binding to specific DNA, as discussed above. Second, even though the population of VDR molecules appeared to be homogeneous with respect to elution from the DNA-cellulose column, this is a low resolution technique that can only resolve populations of molecules with relatively large differences in DNA binding.

In this study we have shown that receptors isolated from rats with renal failure behave similarly to receptors that were isolated from normal rats and incubated in vitro with uremic ultrafiltrate. Scatchard analysis of EMSAs indicated that only slightly more than half of the $\left[{ }^{3} \mathrm{H}\right]$ calcitriol binding VDRs from rats with renal failure (295 vs. control $543 \mathrm{fmol} / \mathrm{pmol}\left[{ }^{3} \mathrm{H}\right]-$ calcitriol binding protein) were capable of binding to the osteocalcin VDRE with a normal $K_{\mathrm{d}}$, and the remainder were unable to bind to the VDRE. In contrast to the previously described DNA-cellulose studies, studies of the binding of VDRs from renal failure rats to DNA-cellulose demonstrated two populations of receptors: one that binds DNA-cellulose normally and the other that binds weakly (9). Thus, in this case the DNAcellulose binding data correlate well with the analysis of binding to a specific VDRE.

A recent study (28) has indicated that enhanced proteolytic degradation of the VDR during its preparation (without protease inhibitors) may occur in renal failure. Protease inhibitors (Trasylol and soybean trypsin inhibitor) were used throughout the preparation of intestinal receptors in the present study. Although addition of soybean trypsin inhibitor in receptor preparations significantly stabilized the intestinal VDR (16), it is possible that the receptors isolated from renal failure rats could be defective forms artificially produced by the action of an endogenous protease during preparation, resulting in a receptor deficient in DNA binding $(29,30)$. However, this seems unlikely as a sucrose gradient analysis of the receptor from control and renal failure rats revealed identical sedimentation coefficients of 3.3 S (9) and the Western blot study showed that the VDRs of renal failure and control animals had identical molecular weights. Most important, the DNA binding defect of VDR extracted from renal failure rats is reproduced by the incubation of normal VDR with uremic ultrafiltrate, and SDS-PAGE analysis demonstrates that this effect of uremic ultrafiltrate is not accounted for by proteolytic activity (Fig. 6).

The DNA binding domain of the VDR has two zinc fingers which contain eight essential cysteine residues (1). This region is sensitive to chemical modification by pyridoxal 5-phosphate and sulfhydryl blocking agents, such as $p$-chloromercuribenzoate and iodoacetamide. The latter chemical substances are purported to block the interaction of VDR with DNA-cellulose (31). Pyridoxal 5-phosphate reacts with e-amino groups of lysine residues of the DNA binding domain of steroid receptors to form Schiff bases, which results in inhibition of steroid receptor binding to DNA-cellulose $(25,32-34)$. This modification could also account for the pyridoxal phosphate-induced inhibition of 
the interaction of VDR with DNA-cellulose (19) and with the osteocalcin (Fig. 2) and osteopontin (not shown) VDREs. Although the mechanism of inhibition of VDR binding to the osteocalcin and osteopontin VDREs by uremic toxins is unknown, reactive aldehydes or ketones may accumulate during uremia and block VDR-VDRE interactions by an analogous Schiff base mechanism. The chemical characterization of such toxins could lead to improved ways of removing those molecules from the plasma of uremic patients or the identification of drugs that would prevent their adverse effects on calcitriol action.

Recent studies have demonstrated that RXR and perhaps other nuclear factors are required for high affinity VDR binding to many $(13,14,35)$, but perhaps not all (36), VDREs. Indeed, in these studies we find that the endogenous VDR binds to the osteopontin VDRE as a heterodimer with RXR, and that $E$. coli-derived VDR and RXR only bind to this VDRE as a heterodimer. Therefore, it is worth considering whether an effect of uremic toxins on RXR could underlie our results. However, deficient production of RXR in renal failure is not a likely explanation for our data since the in vitro incubation of normal receptors with uremic ultrafiltrate recapitulates the defect seen with VDR extracted from renal failure rats. Furthermore, the use of $E$. coli-derived VDR and RXR allowed us to demonstrate that the inhibitory effect of U-UF is due to an interaction of U-UF with VDR, not RXR. This result is important for two reasons. First, RXR is a heterodimerization partner for thyroid hormone, retinoic acid, and other receptors (37) in addition to VDRs. Had RXR been the target for U-UF one would predict that this effect might indirectly impair gene regulation by numerous receptors in renal failure. Second, it indicates that the effect of U-UF on VDR-DNA binding cannot be generalized to all nuclear receptors. Thus, there is some specificity to this toxic effect of U-UF. The exact reason for this specificity is unknown and must await chemical identification of the toxic substance(s).

These studies were initiated in an attempt to explain the calcitriol resistance associated with renal failure. An important question is whether the ability of U-UF to impair VDR-DNA interactions in EMSAs has relevance to the actions of calcitriol within the cell. To address this we established a transient transfection model system. This model allowed us to show that incubation of cells with media containing U-UF does indeed impair the ability of calcitriol to induce the expression of a target gene. This effect could not be accounted for by impaired VDR expression, and U-UF does not impair calcitriol-VDR binding (38). Thus, our results are consistent with the hypotheses that U-UF contains a toxin(s) that interacts with the VDR to impair its DNA binding within cells and that this results in a diminished calcitriol response in renal failure. This transfection system should be a valuable model to study this process, especially since whole animal studies are exceedingly complex and difficult to interpret. For example, some investigators have found that renal failure is associated with a decreased number of VDRs $(39,40)$, which obviously could lead to calcitriol resistance. However, the decreased number of VDRs in renal failure could itself be taken as evidence in support of the decreased DNA binding mechanism. This is because calcitriol has been found to induce VDR expression (41). Although the mechanism of this effect is not clear $(41,42)$, if it is VDR mediated then interaction of the uremic toxin(s) with VDRs could explain the decreased VDR expression in renal failure. VDR expression is not inhibited by U-UF in our model system presumably because the VDR cDNA is expressed from a cytomegalovirus promoter that itself is not calcitriol responsive.

In summary, the VDR from rats with renal failure showed decreased binding to VDREs compared with the VDR from normal rats. A similar inhibitory effect was found when a uremic ultrafiltrate was incubated with normal endogenous or recombinant VDRs. This effect was due to an interaction of UUF with the VDR, not RXR. Furthermore, U-UF impaired the ability of calcitriol-VDR complexes to induce expression from a target gene in a transfection system. Taken together, the results suggest that impaired VDR binding to VDREs could at least in part underlie the end-organ resistance to calcitriol in renal failure.

\section{Acknowledgments}

The vitamin D metabolites used in this study were kindly provided by Dr. M. Uskokovic (Hoffman-LaRoche, Nutley, NJ) and Organon Inc.(West Orange, NJ). The cDNA for the human vitamin D receptor was provided by Dr. J. W. Pike (Baylor College of Medicine, Houston, $\mathrm{TX}$ ). The RXR $\alpha$ cDNA and the anti-RXR monoclonal antibody were kindly provided by Dr. P. Chambon (Institut de Chimie Biologique, Strasbourg, France). The osteocalcin VDRE oligonucleotide was kindly provided by Dr. H. DeLuca (University of Wisconsin, Madison, WI). We wish to thank Neil Faulkner, Yin Xu, and Rajal Patel for technical assistance.

This work was supported by a grant-in-aid from the Extramural Grant Program, Baxter Health Care Corporation.

\section{References}

1. O'Malley, B. 1990. The steroid receptor superfamily: more excitement predicted for the future. Mol. Endocrinol. 4:363-369.

2. Haussler, M., C. A. Donaldson, M. A. Kelly, D. J. Mangelsdorf, S. L. Marion, and J. W. Pike. 1985. Function and mechanism of action of the 1,25dihydroxyvitamin $\mathrm{D}_{3}$ receptor. In Vitamin D. Chemical, Biochemical and Clinical Update. A. Norman, K. Schaefer, G. H. Grigoleit, and D. V. Herrath, editors. Walter deGreyter, Berlin/New York. 83-92.

3. Pike, J. W. 1987. Emerging concepts on the biologic role and mechanism of action of 1,25-dihydroxyvitamin $\mathrm{D}_{3}$. Steroids. 49:3-27.

4. Walling, M. W., D. V. Kimberg, R. H. Wasserman, and R. R. Feinberg. 1976. Duodenal active transport of calcium and phosphate in vitamin D-deficient rats: effects of nephrectomy, Cestrum diurnum, and 1 alpha,25-dihydroxyvitamin $D_{3}$. Endocrinology. 98:1130-1134.

5. Fukagawa, M., S. Kaname, T. Igarashi, E. Ogata, and K. Kurokawa. 1991. Regulation of parathyroid hormone synthesis in chronic renal failure in rats. Kidney Int. 39:874-881.

6. Patel, S., R. U. Simpson, and C. H. Hsu. 1989. Effect of vitamin D metabolites on calcitriol metabolism in experimental renal failure. Kidney Int. 36:234239.

7. Patel, S. R., H. Q. Ke, and C. H. Hsu. 1994. Effect of vitamin D metabolites on calcitriol degradative enzymes in renal failure. Kidney Int. 45:509-514.

8. Hsu, C. H., S. R. Patel, and E. W. Young. 1992. Mechanism of decreased calcitriol degradation in renal failure. Am. J. Physiol. 262:F192-F198.

9. Hsu, C. H., R. S. Patel, and R. Vanholder. 1993. Mechanism of decreased intestinal calcitriol receptor concentration in renal failure. Am. J. Physiol. 264:F662-F669.

10. Hughes, M. R., P. J. Malloy, D. G. Kieback, R. A. Kesterson, J. W. Pike, D. Feldman, and B. W. O'Malley. 1988. Point mutations in the human vitamin D receptor gene associated with hypocalcemic rickets. Science (Wash. DC). 242:1702-1705

11. Sone, T., R. A. Scott, M. R. Hughes, P. J. Malloy, D. Feldman, B. W. O'Malley, and J. W. Pike. 1989. Mutant vitamin D receptors which confer hereditary resistance to 1,25-dihydroxyvitamin $\mathrm{D}_{3}$ in humans are transcriptionally inactive in vitro. J. Biol. Chem. 264:20230-20234.

12. Malloy, P. J., Z. Hochberg, J. W. Pike, and D. Feldman. 1989. Abnormal binding of vitamin $\mathrm{D}$ receptors to deoxyribonucleic acid in a kindred with vitamin D-dependent rickets, type II. J. Clin. Endocrinol. \& Metab. 68:263-269.

13. Ross, T. K., V. E. Moss, J. M. Prahl, and H. F. DeLuca. 1992. A nuclear protein essential for binding of rat 1,25-dihydroxyvitamin $D_{3}$ receptor to its responsive elements. Proc. Natl. Acad. Sci. USA. 89:256-260. 
14. Sone, T., S. Kerner, and J. W. Pike. 1991. Vitamin D receptor interaction with specific DNA. Association as a 1,25-dihydroxyvitamin $D_{3}$-modulated heterodimer. J. Biol. Chem. 266:23296-23305.

15. Hsu, C. H., R. Vanholder, S. Patel, R. R. DeSmet, P. Sandra, and S. M. G. Rigoir. 1991. Subfractions in uremic plasma ultrafiltrate inhibit calcitriol metabolism. Kidney Int. 40:868-873.

16. Hirst, M., and D. Feldman. 1986. Cleavage of the rat intestinal 1,25dihydroxyvitamin $D_{3}$ receptor by an endogenous protease to a form with defective DNA binding. Arch Biochem. Biophys. 250:153-161.

17. Bradford, M. M. 1976. A rapid and sensitive method for the quantitation of microgram quantities of protein utilizing the principle of protein-dye binding. Anal. Biochem. 72:248-254.

18. Demay, M. B., M. S. Kiernan, H. F. DeLuca, and H. M. Kronenberg. 1992. Characterization of 1,25-dihydroxyvitamin $D_{3}$ receptor interactions with target sequences in the rat osteocalcin gene. Mol. Endocrinol. 6:557-562.

19. Liao, J., K. Ozono, T. Sone, D. P. McDonnell, and J. W. Pike. 1990. Vitamin D receptor interaction with specific DNA requires a nuclear protein and 1,25-dihydroxyvitamin $D_{3}$. Proc. Natl. Acad. Sci. USA. 87:9751-9755.

20. Jurutka, P. W., J. C. Hsieh, P. N. MacDonald, C. M. Terpening, C. A. Haussler, M. R. Haussler, and G. K. Whitfield. 1993. Phosphorylation of serine 208 in the human vitamin $\mathrm{D}$ receptor. The predominant amino acid phosphorylated by casein kinase II, in vitro, and identification as a significant phosphorylation site in intact cells. J. Biol. Chem. 268:6791-6799.

21. Noda, M., R. L. Vogel, A. M. Craig, J. Prahl, H. F. DeLuca, and D. T. Denhardt. 1990. Identification of a DNA sequence responsible for binding of the 1,25-dihydroxyvitamin $D_{3}$ receptor and 1,25-dihydroxyvitamin $D_{3}$ enhancement of mouse secreted phosphoprotein 1 (Spp-1 or osteopoptin) gene expression. Proc. Natl. Acad. Sci. USA. 87:9995-9999.

22. Subauste, J. S., R. W. Katz, and R. J. Koenig. 1994. DNA binding specificity and function of retinoid X receptor $\alpha$. J. Biol. Chem. 269:30232-30237.

23. Rosen, E. D., E. G. Beninghof, and R. J. Koenig. 1993. Dimerization interfaces of thyroid hormone, retinoic acid, vitamin $\mathrm{D}$ and retinoid $\mathrm{X}$ receptors. J. Biol. Chem. 268:11534-11541.

24. Hsu, C. H., and S. Patel. 1990. Effect of pyridoxal 5'-phosphate on calcitriol metabolism. J. Am. Soc. Nephrol. 1:585.

25. Cake, M. H., D. M. DiSorbo, and G. Litwack. 1978. Effect of pyridoxal phosphate on the DNA binding site of activated hepatic glucocorticoid receptor. J. Biol. Chem. 253:4886-4891.

26. Lian, J., C. Stewart, E. Puchacz, S. Mackowiak, V. Schalhoub, D. Collart, G. Zambetti, and G. Stein. 1989. Structure of the rat osteocalcin gene and regulation of vitamin D-dependent expression. Proc. Natl. Acad. Sci. USA. 86:11431147.

27. Kerner, S. A., R. A. Scott, and J. W. Pike. 1989. Sequence elements in the human osteocalcin gene confer basal activation and inducible response to hormonal vitamin $\mathrm{D}_{3}$. Proc. Natl. Acad. Sci. USA. 86:4455-4459.

28. Szabo, A., J. Merke, M. Thomasset, and E. Ritz. 1991. No decrease of
$1,25(\mathrm{OH})_{2} \mathrm{D}_{3}$ receptors and duodenal calbindin-D9k in uraemic rats. Eur. J. Clin. Invest. 21:521-526.

29. Allegretto, E. A., and J. W. Pike. 1985. Trypsin cleavage of chick 1,25dihydroxyvitamin $D_{3}$ receptors. Generation of discrete polymers which retain hormone but are unreactive to DNA and monoclonal antibody. J. Biol. Chem. 260:10139-10145.

30. Allegretto, E. A., J. W. Pike, and M. R. Haussler. 1987. Immunochemical detection of unique proteolytic fragments of the chick 1,25-dihydroxyvitamin $D_{3}$ receptor. Distinct 20-k Da DNA-binding and 45-k Da hormone-binding species. J. Biol. Chem. 262:1312-1319.

31. Pike, J. W. 1981. Evidence for a reactive sulfhydryl in the DNA binding domain of the 1,25-dihydroxyvitamin $\mathrm{D}_{3}$ receptor. Biochem. Biophys. Res. Commun. 100:1713-1719.

32. Muller, R. E., A. Traish, and H. H. Wotiz. 1980. Effects of pyridoxal 5'phosphate on uterine estrogen receptor. I. Inhibition of nuclear binding in cellfree system and intact uterus. J. Biol. Chem. 255:4062-4067.

33. Mulder, E., L. Vrij, and J. A. Foekens. 1980. Inhibition of nucleic acid and chromatin binding of the rat prostate androgen receptor by pyridoxal phosphate, heparin and Cibacron blue. Steroids. 36:633-645.

34. Nishigori, H., and D. Toft. 1979. Chemical modification of the avian progesterone receptor by pyridoxal 5'-phosphate. J. Biol Chem 254:9155-9161.

35. Nakajima, S., J. C. Hsieh, P. N. MacDonald, M. A. Galligan, C. A. Haussler, G. K. Whitfield, and M. R. Haussler. 1994. The C-terminal region of the vitamin D receptor is essential to form a complex with a receptor auxiliary factor required for high affinity binding to the vitamin D-responsive element. Mol. Endocrinol. 8:159-172.

36. Carlberg, C., I. Bendik, A. Wyss, E. Meier, L. J. Sturzenbecker, J. F. Grippo, and W. Hunziker. 1993. Two nuclear signalling pathways for vitamin D. Nature (Lond.). 361:657-660.

37. Kliewer, S. A., K. Umesono, D. J. Mangelsdorf, and R. M. Evans. 1992. Retinoid X receptor interacts with nuclear receptors in retinoic acid, thyroid hormone and vitamin- $D_{3}$ signalling. Nature (Lond.). 355: 446-449.

38. Patel, S., H. Q. Ke, R. Vanholder, and C. H. Hsu. 1994. Inhibition of nuclear uptake of calcitriol receptor by uremic ultrafiltrate. Kidney Int. 46:129133.

39. Korkor, A. B. 1987. Reduced binding of $\left[{ }^{3} \mathrm{H}\right] 1,25$-dihydroxyvitamin $D_{3}$ in the parathyroid glands of patients with renal failure. N. Engl. J. Med. 316:15731577.

40. Fukuda, N., H. Tanaka, Y. Tominaga, M. Fukagawa, K. Kurokawa, and Y. Seino. 1993. Decreased 1,25-dihydroxyvitamin $D_{3}$ receptor density is associated with a more severe form of parathyroid hyperplasia in chronic renal failure. J. Clin. Invest. 92:1436-1443.

41. McDonnell, D. P., D. J. Mangelsdorf, J. W. Pike, M. R. Haussler, and B. W. O'Malley. 1987. Molecular cloning of complementary DNA encoding the avian receptor for vitamin D. Science (Wash. DC). 235:1214-1217.

42. Wiese, R. J., S. A. Uhland, T. K. Ross, J. M. Prahl, and H. F. DeLuca. 1992 Up-regulation of the vitamin $D$ receptor in response to 1,25 - dihydroxyvitamin $D_{3}$ results from ligand-induced stabilization. J. Biol. Chem. 267:20082-20086. 